\title{
45S5 Bioglass-Derived Glass-Ceramic Scaffolds Containing Niobium Obtained by Gelcasting Method
}

\author{
Lilian de Siqueira ${ }^{a}$, Liliana Grenho ${ }^{b, c}$, Maria H. Fernandes ${ }^{b, c}$, Fernando J. Monteiro ${ }^{d, e, f}$, \\ Eliandra S. Trichês ${ }^{a}$ * (1) \\ ${ }^{a}$ Universidade Federal de São Paulo, Instituto de Ciência e Tecnologia, 12231-280, São José dos \\ Campos, SP, Brasil \\ ${ }^{b}$ Universidade do Porto, Faculdade de Medicina Dentária, 4200-393, Porto, Portugal \\ 'Universidade do Porto, Rede de Química e Tecnologia (REQUIMTE), Laboratório Associado para a \\ Química Verde (LAQV), 4051-401, Porto, Portugal \\ ${ }^{d}$ Universidade do Porto, i3S - Instituto de Investigação e Inovação em Saúde, 4200-135, Porto, Portugal \\ ${ }^{e}$ Universidade do Porto, Instituto de Engenharia Biomédica (INEB), 4200-135, Porto, Portugal \\ ${ }^{f}$ Universidade do Porto, Faculdade de Engenharia, Departamento de Engenharia Metalúrgica e de \\ Materiais (DEMM), 4200-465, Porto, Portugal
}

Received: September 03, 2020; Revised: November 06, 2020; Accepted: December 10, 2020

Scaffolds of bioglass derived from BG45S5 (45 wt $\% \mathrm{SiO}_{2}, 24.5 \mathrm{wt} \% \mathrm{CaO}, 24.5 \mathrm{wt} \% \mathrm{Na}_{2} \mathrm{O}$ and $6 \mathrm{wt} \% \mathrm{P}_{2} \mathrm{O}_{5}$ ) containing $10 \mathrm{wt} \%$ niobium were prepared by gelcasting method. The scaffolds presented a $3 \mathrm{D}$ porous structure with interconnected and spherical pores (pore size range $100 \mu \mathrm{m}$ to $500 \mu \mathrm{m})$ and high porosity $(89 \%)$, similar to trabecular architecture of spongy bone. The compressive strength was $0.18 \pm 0.03 \mathrm{MPa}$ which is acceptable for bone repair applications. The in vitro biological studies showed cytocompatibility for human osteoblastic cells as well tendency for higher alkaline phosphatase activity. Therefore, the findings here suggest the great potential of the scaffolds for using in bone tissue engineering.

Keywords: Bioglass, Niobium oxide, Scaffold; Gelcasting method, Porous materials, Bone tissue engineering.

\section{Introduction}

Bioactive glasses (BGs) are outstanding materials in tissue engineering due to their high bioactivity and biocompatibility ${ }^{1}$. In the last decades, several silicate glass compositions have been developed and investigated for a number of applications, including bone substitute materials, dental and coating applications and hard and soft tissue repair scaffolds ${ }^{2}$. Additionally, research focuses on the addition of therapeutic ions with physiological activities and therapeutic properties in BGs, which are released during the process of dissolving of the material ${ }^{3,4}$, improving its performance $^{5}$. Among the therapeutic ions, strontium ${ }^{6}$, cobalt $^{7}$ and niobium ${ }^{8}$ have been explored.

In the literature, some reports about production of bioactive glass and glass-ceramic containing niobium have been found ${ }^{8-11}$. For example, Souza et al..$^{11}$ shows in vitro and in vivo studies of a novel melt-derived $\mathrm{Nb}$ substituted 45S5 bioglass that exhibited similar release profile for $\mathrm{Si}$, $\mathrm{Na}$ and $\mathrm{Ca}$ species compared to BG45S5, in addition to the release of niobium species by the compositions of $\mathrm{Nb}$ containing glass. The release of niobium species may have been responsible for the observed enhanced osteogenic and osteostimulative properties.

*e-mail: eliandra.sousa@unifesp.br
Recently, Souza et al. also studied the biocompatibility of a bioactive glass of calcium and sodium silicate containing $2.6 \mathrm{~mol} \% \mathrm{Nb}_{2} \mathrm{O}_{5}$ through a variety of in vivo and in vitro experiments and the results were compared with the archetypal 45S5 bioglass. Tests have shown that the material does not cause damage to elevated metabolic and excretory organs, such as the liver and kidneys and not have genetic toxicity. These results attest that this glass composition is biocompatible and can be implanted in the body without causing damage.

In the present work, highly bioactive glass-ceramics scaffolds containing niobium for bone repair applications were produced by gelcasting method. The aim was to demonstrate that it is possible to obtain 3D structures with suitable porosity by a simple and cheap method. The scaffolds were characterized according to its physical, mechanical and biological properties.

\section{Materials and Methods}

\subsection{Preparation of BGNb10 scaffolds by gelcasting method}

The chemical composition of BG45S5 $\left(45 \mathrm{wt} \% \mathrm{SiO}_{2}\right.$, $24.5 \mathrm{wt} \% \mathrm{CaO}, 24.5 \mathrm{wt} \% \mathrm{Na}_{2} \mathrm{O}$ and $6 \mathrm{wt} \% \mathrm{P}_{2} \mathrm{O}_{5}$ ) was modified by replacing part of the $\mathrm{SiO}_{2}$ in the glass matrix with niobium, 
in the oxide form $\left(\mathrm{Nb}_{2} \mathrm{O}_{5}\right)$ in the proportion of $10 \mathrm{wt} \%$. This composition was named BGNb10. Regarding this purpose, high purity $\mathrm{SiO}_{2}, \mathrm{Na}_{2} \mathrm{CO}_{3}, \mathrm{CaCO}_{3}$ and $\mathrm{P}_{2} \mathrm{O}_{5}$ powders $(>99.9 \%)$ were weighed to obtain the glass composition. All precursor reagents were purchased from Sigma-Aldrich (St. Louis, $\mathrm{MO})$, except the niobium oxide $\left(\mathrm{Nb}_{2} \mathrm{O}_{5}\right.$, optical grade, $>99.5 \%$ ), donated by the CBMM (Companhia Brasileira de Metalurgia e Mineração, Araxá, Minas Gerais, Brazil). Briefly, the powder, after being mixed in a conventional ball mill for $2 \mathrm{~h}$, was placed in a fused zirconia-alumina-silica (ZAS) crucible and heated to an intermediate step at $900{ }^{\circ} \mathrm{C}$ for $90 \mathrm{~min}$ to degasify the melt, followed by a second step at $1350{ }^{\circ} \mathrm{C}$ for $15 \mathrm{~min}$ followed by quenching in deionized water at room temperature ${ }^{1}$. The coarse frit form of the glass was collected and dried overnight at $100{ }^{\circ} \mathrm{C}$. The glass was milled into porcelain mortar, passed through a 140 mesh sieve, followed up by an intense grinding in a ball mill (MA500, Marconi, Piracicaba, SP, Brazil) with zirconia milling media of $2.5 \mathrm{~mm}$ of diameter. The resulting powder was analyzed by laser diffraction (CILAS 1190L, Madison, WI, USA) and by X-ray diffraction (Shimadzu XRD7000, CuK $\alpha$ radiation, $\left.2 \theta=10-60^{\circ}, 25 \mathrm{~mA}, 40 \mathrm{kV}\right)$. As result the glass powder presented a mean particle size of $4.02 \mu \mathrm{m}\left(\mathrm{D}_{50}\right.$ value $)$ and a particle size distribution ranging from $0.92 \mu \mathrm{m}\left(\mathrm{D}_{10}\right.$ value $)$ to $9.68 \mu \mathrm{m}\left(\mathrm{D}_{90}\right.$ value $)$ and presented amorphous structure.

The BGNb10 scaffolds were fabricated using the gelcasting method. Slurries with solid content of 30 vol.-\% of the glass powder were prepared by dispersing the powder in an aqueous solution containing 20 vol.- $\%$ of organic monomers (methacrylamide - MAM, N,N,N',N'-hydroxymethyl acrylamide - HMAM and methylenebisacrylamide - MBAM) at a molar ratio of 3:3:1 (MAM:HAMAM:MBAM) as previously published elsewhere ${ }^{1}$. Briefly, a non-ionic surfactant $(0.2 \%$ related to slurry mass, Lutensol ON-110, BASF) was added into the slurry to produce the foam after being stirred for $3 \mathrm{~min}$ with a mixer. Ammonium persulfate (APS, Vetec Química Fina Ltda, RJ, Brazil) and N,N,N,N'-tetramethylethylenediamine (TEMED, Sigma-Aldrich, St. Louis, MO, USA) at a molar ratio of 1:3.5 were used as initiator and catalyst for gelation reaction, respectively. The foam was poured into $250 \mathrm{~mL}$ beakers where it remained for gelation. After gelation, the foams were demoulded and dried at $40{ }^{\circ} \mathrm{C}$ for $24 \mathrm{~h}$ and then the samples were core-drilled (cylinders, $\mathrm{d}=6 \mathrm{~mm}$ and $\mathrm{h}=12 \mathrm{~mm}$ ). The heat treatment was performed as follow: i) samples were fired at $500{ }^{\circ} \mathrm{C}$ (heating rate of $1{ }^{\circ} \mathrm{C} / \mathrm{min}$ and dwell time of $1 \mathrm{~h}$ ) to eliminate all organic components; ii) samples were sintered at $850{ }^{\circ} \mathrm{C}$ (heating rate of $5^{\circ} \mathrm{C} / \mathrm{min}$ and dwell time of $2 \mathrm{~h}$ ).

\subsection{Scaffolds Characterization}

A fracture surface of the BGNb10 scaffolds was observed by scanning electron microscopy (SEM) (JEOL 6360-LEV). In order to investigate the crystalline phases formed after the heat treatment, the powdered scaffolds were analyzed by X-ray diffraction (Shimadzu XRD7000, CuK $\alpha$ radiation, $\left.2 \theta=10-60^{\circ}, 25 \mathrm{~mA}, 40 \mathrm{kV}\right)$.

Total porosity of glass scaffolds was determined according to Equations 1 and 2 . The geometric density ( $\rho_{\text {scaffolds }}$ ) of cylindrical samples was calculated using their dimensions (height and diameter) and weight. The theoretical density of the scaffolds $\left(\rho_{t}\right)$ was calculated considering the density of the $45 \mathrm{~S}^{\circledR}$ Bioglass $\left(\rho_{45 \mathrm{~S} 5 \circledast \text { Bioglass }}\right)$ equal to $2.7 \mathrm{~g} . \mathrm{cm}^{-3} 12$ and the $\mathrm{Nb}_{2} \mathrm{O}_{5}\left(\rho_{\mathrm{Nb} 2 \mathrm{O} 5}\right)$ equal to $4.6 \mathrm{~g} \cdot \mathrm{cm}^{-3}{ }^{13} \cdot X_{\mathrm{BG} 45 \mathrm{~S} 5}$ and $X_{\mathrm{Nb} 2 \mathrm{O} 5}$ are the mass fractions of each phase added for the preparation of the scaffolds.

$$
\begin{aligned}
& P(\%)=1-\left(\frac{\rho_{\text {scaffolds }}}{\rho_{t}}\right) \times 100 \\
& \rho_{t}=\left[\left(X_{B G 45 S 5} \times \rho_{45 S 5^{\circledR} \text { Bioglass }}\right)+\left(X_{N_{2} O_{5}} \times \rho_{N b_{2} O_{5}}\right)\right]
\end{aligned}
$$

The compression strength of the scaffolds (cylindrical form, $\mathrm{h} / \mathrm{d}=2$ ) was determined by using a universal testing machine (DL2000, EMIC, São José dos Pinhais, PR, Brazil) at cross-head speed of $0.5 \mathrm{~mm} \cdot \mathrm{min}^{-1}$, with the load cell of $5 \mathrm{kN}$. Polytetrafluoroethylene (PTFE) layers were used at the two ends of the testing foams to avoid edge effects (fragmentation of edges and sliding) during loading. Results of porosity and compressive strength are reported as mean \pm standard deviation calculated on 10 specimens.

\subsection{Biological analysis of the scaffolds}

In vitro cytocompatibility was performed based on the standard cytotoxicity assessment set by the International Standardization Organization (ISO 10993), using an indirect assay. Briefly, for the preparation of the extracts, $0.1 \mathrm{~g}$ of BGNb10 scaffolds were incubated in $1 \mathrm{~mL}$ of cell culture medium - $\alpha$-Minimal Essential Medium ( $\alpha$-MEM) supplemented with $10 \%$ fetal bovine serum, $100 \mathrm{IU} / \mathrm{mL}$ penicillin, and $100 \mu \mathrm{g} / \mathrm{mL}$ streptomycin (all reagents from Gibco), for $24 \mathrm{~h}$ at $37^{\circ} \mathrm{C}$, in a humidified atmosphere of $5 \% \mathrm{CO}_{2}$. After incubation, the medium, from now on designated as extracts, was collected and serially diluted in cell culture medium. Prior to the exposure to these extracts, MG-63 osteoblastic cells were seeded at $10^{5}$ cells $/ \mathrm{mL}$ (96-well plates, $100 \mu \mathrm{L}$ ) and incubated for $24 \mathrm{~h}$ at $37^{\circ} \mathrm{C}$ in a humidified atmosphere of $5 \% \mathrm{CO}_{2}$. After incubation, the medium was replaced by the extracts' dilutions and the cultures were further maintained under standard incubation conditions for 2 and 6 days. Cytocompatibility was evaluated regarding cell metabolic activity and alkaline phosphatase (ALP) activity.

After $48 \mathrm{~h}$ of exposure to the extracts, cell metabolic activity was determined using the MTT assay (Sigma Aldrich, St. Louis, MO, USA). Briefly, 10\% (v/v) of MTT solution was added to each well, and the cells were incubated for $3 \mathrm{~h}$. After removing the culture medium, the resulting formazan crystals were dissolved by adding $100 \mu \mathrm{L}$ of dimethyl sulfoxide solvent (Sigma-Aldrich, St. Louis, MO, USA) to each well. The plates were shaken at room temperature for 10 min to dissolve the crystals and the absorbance were then analyzed at $550 \mathrm{~nm}$ using a microplate reader (Synergy HT, BioTek). The absorbance value readings were normalized to untreated control cultures $(100 \%)$.

Cell viability was evaluated through live/dead staining, which is a two-color fluorescence assay that simultaneously determines live and dead cells. Live cells have the ability to cleave and retain a highly fluorescence calcein appearing as green in color, while died cells or cells with damaged membrane allow the entry of propidium iodide (PI) and, therefore, they appeared as red. After $24 \mathrm{~h}$ exposure, the 
extracts were removed and cells were washed twice with phosphate buffer solution (PBS, Sigma-Aldrich, St. Louis, MO, USA). Calcein AM (Sigma-Aldrich, St. Louis, MO, USA) was diluted in cell culture medium without phenol red and PI (Sigma-Aldrich, St. Louis, MO, USA) solution was used as supplied. Each solution was added to cells and incubated for $30 \mathrm{~min}$ at $37^{\circ} \mathrm{C}$, protected from light. Cells were then visualized with an inverted fluorescence microscope (Axiovert 200M, Carl Zeiss Microscopy GmbH, Germany) with green (488 nm) and red (594 nm) filters.

After 6 days of culture, cells were analysed for ALP activity. Cell lysates were prepared in $0.1 \%(\mathrm{v} / \mathrm{v})$ Triton X-100 (Sigma-Aldrich, St. Louis, MO, USA) and the enzyme activity was evaluated through the hydrolysis of $\rho$-nitrophenyl phosphate (Sigma-Aldrich, St. Louis, MO, USA), in alkaline buffer solution, at $\mathrm{pH} 10$. After $1 \mathrm{~h}$ incubation at $37^{\circ} \mathrm{C}$, the product ( $\rho$-nitrophenol) was measured in a plate reader at an absorbance of $405 \mathrm{~nm}$ (Synergy HT, BioTek). ALP activity

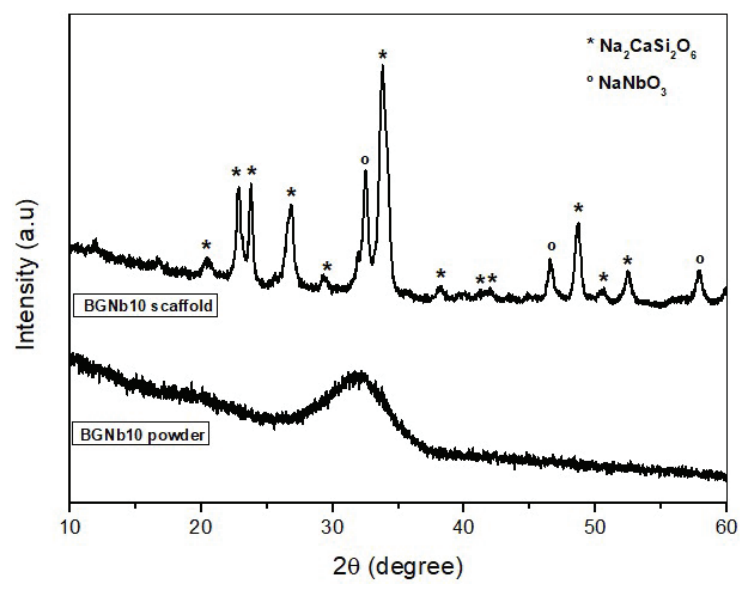

Figure 1. XRD patterns of BGNb10 glass powder and BGNb10 scaffolds prepared by gelcasting method and sintered at $850^{\circ} \mathrm{C} / 2 \mathrm{~h}$. was normalized to total protein content and expressed as nmol of $\rho$-nitrophenol produced per $\mu \mathrm{g}$ of protein. Total protein content was measured using the Bio-Rad DC protein assay (Bio-Rad Laboratories), according to manufacturer instructions, with bovine serum albumin used as standard.

\subsection{Statistical analysis}

Results were expressed as mean \pm standard deviation. The biological assays were performed in triplicate, in three independent experiments. The results were compared using the one-way analysis of variance (One-way ANOVA) followed by post hoc Tukey HSD multiple comparison test (IBM ${ }^{\circledR}$ SPSS $^{\circledR}$ Statistics, vs. 20.0, Chicago). Levels of $\mathrm{p}<0.05$ were considered to indicate the significance level.

\section{Results and Discussion}

The XRD patterns of the BGNb10 glass powder and the BGNb10 scaffolds sintered at $850{ }^{\circ} \mathrm{C}$ are show in Figure 1. It is possible to observe the amorphous nature of the glass powder by absence of diffraction peaks. On the other hand, it was formed crystalline phase in the scaffolds after the heat treatment. The peaks correspond to $\mathrm{Na}_{2} \mathrm{CaSi}_{2} \mathrm{O}_{6}$ (JCPDS 77-2189) and $\mathrm{NaNbO}_{3}$ (JCPDS 014-0603) phases, where the first one appears as majority phase.

Morphological analysis by SEM (Figure 2) shows that the BGNb10 scaffolds present a homogeneous pore distribution, high degree of interconnection between them and average pore size in the range of $100 \mu \mathrm{m}$ to $500 \mu \mathrm{m}$ (Figure 2A1-A4). Figure $2 \mathrm{~A} 5$ and $2 \mathrm{~A} 6$ shows the densification of the scaffolds as well as the presence of crystalline phase in needles form, in accordance with the XRD analysis.

The porosity achieved was $89.2 \pm 1.4 \%$ while the mechanical strength was $0.18 \pm 0.03 \mathrm{MPa}$ and the relative density $\left(\rho / \rho_{0}\right.$ ) was 0.127 (Table 1 ). According to Elsayed et al. ${ }^{14}$ the compressive strength of cancellous bone is in the range of $0.2 \mathrm{MPa}$ to $4.0 \mathrm{MPa}$ when the relative density is $\sim 0.1$.
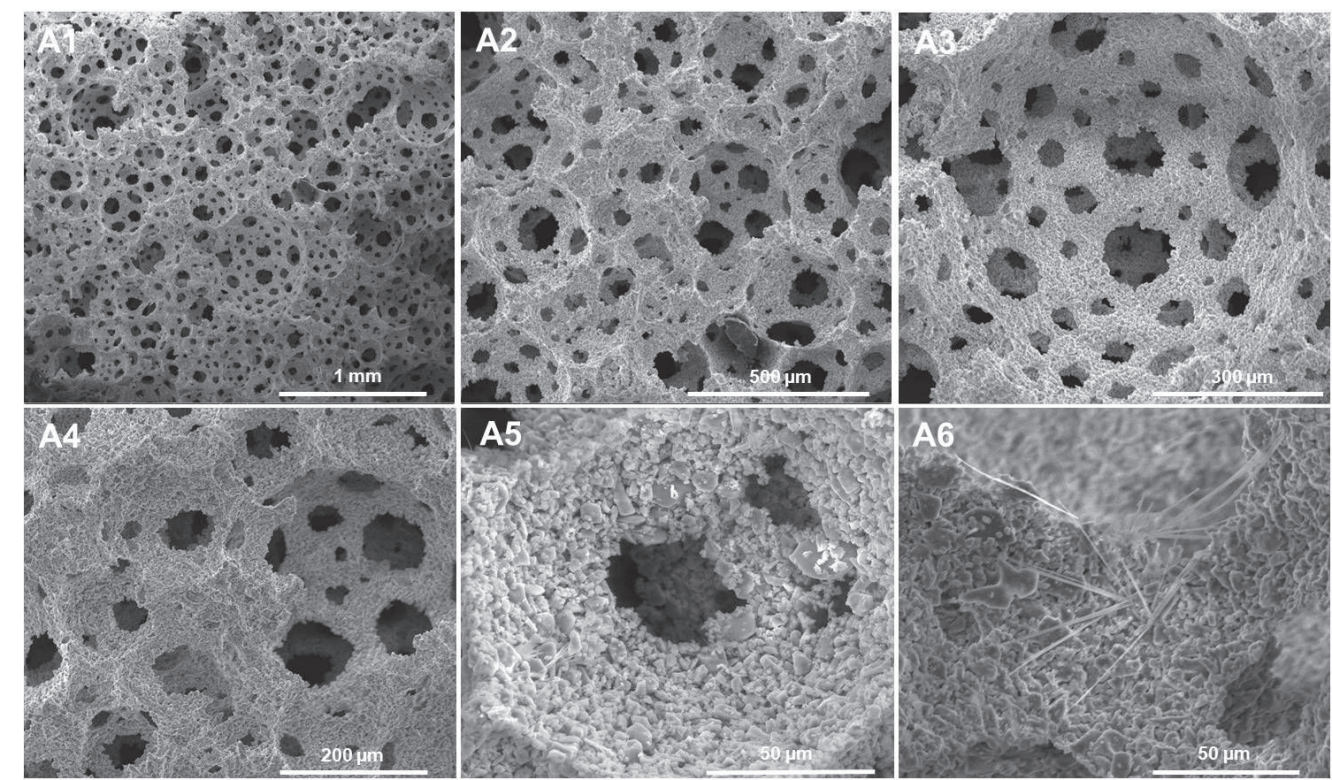

Figure 2. SEM micrographs of BGNb10 scaffolds (A1, A2, A3, A4, A5, A6) prepared by gelcasting method and sintered at $850{ }^{\circ} \mathrm{C} / 2 \mathrm{~h}$. 
In our work, the BGNb10 scaffolds' compressive strength is closer to the lower limit of this range. However the scaffolds presented enough mechanical resistance to be handled properly during the tests.

The data were not compared with literature values, as far as we know, this is the first time that 45S5 bioglass-derived glass-ceramic scaffolds containing niobium have been prepared by gelcasting method. Only results of scaffolds prepared by sol-gel method were found ${ }^{15}$, which hinders the direct comparison between the results since the process of obtaining scaffolds influences directly in the physical and mechanical properties of the scaffold.

For biological evaluation none of the dilutions of the extracts was found cytotoxic to MG-63 cells (Figure 3A). In fact, the cell viability of osteoblastic cells cultured at various dilutions of BGNb10 scaffolds extracts was superior to the control adopted. This fact is believed to be due to the presence of $\mathrm{Nb}$ in the composition of the bioglass. The addition of $\mathrm{Nb}_{2} \mathrm{O}_{5}$ caused a significant increase in cell viability, which reinforces its use as a therapeutic ion. Recently, similar results of non-cytotoxic behavior involving niobium were observed in the study by Capanema et al. ${ }^{16}$ and Souza et al. ${ }^{8}$. In the work of Capanema et al. ${ }^{16}$, a preliminary cytocompatibility response of niobium-doped hydroxyapatite ( $\mathrm{Nb}-\mathrm{HA}$ ) nanoparticles was obtained by culturing human osteoblast cells using MTT and resazurin assays, which did not presented cytotoxicity of niobium-linked hydroxyapatite. Souza et al. investigated the biocompatibility of a bioactive sodium calcium silicate glass containing $2.6 \mathrm{~mol} \% \mathrm{Nb}_{2} \mathrm{O}_{5}$ (denoted BGPN2.6) and compare the results with the archetypal 45S5 bioglass. The BGPN2.6 glass was not cytotoxic to bone-marrow-derived mesenchymal stem cells showing excellent cytocompatibility. Besides this, it was observed that $\mathrm{Nb}$-containing glass was capable of stimulating the regeneration of a 5-mm calvarial defect in 56 days. In our study, as a functional parameter of MG-63 cells, ALP activity was also evaluated. ALP is a characteristic osteoblastic marker with a major role in the initiation of the mineralization process ${ }^{17}$. As shown in Figure 3B, ALP levels were visibly/significantly higher for cells exposure to BGNb10 scaffolds extracts as compared to the control. Thus, the BGNb10 scaffolds when are in contact with tissues may affect cell behavior showing that the presence of niobium dispersed in the matrix promotes more effective regeneration.

A previous work carried out by our research group showed evidences that when the content of $\mathrm{Nb}_{2} \mathrm{O}_{5}$ added to the composition of BG45S5 is $10 \mathrm{wt} \%$ a new structure, open and fragmented, can be formed which is interesting from the biological point of view. It is known that the biocompatibility of $45 \mathrm{~S} 5$ Bioglass ${ }^{\circledR}$ occurs by the ionic dissolution products $(\mathrm{Ca}, \mathrm{Si}, \mathrm{Na} \text { and } \mathrm{P})^{18-20}$. As reported by Lopes et al. ${ }^{21}$, the elemental analysis using Inductively Coupled Plasma Optical Emission Spectroscopy (ICP-OES) revealed that the ionic products of niobium-containing glass (45S5 Bioglass containing 1, 2.5 and $5 \mathrm{~mol} \%$ of niobium) are similar to those from $45 \mathrm{~S} 5$, apart from trace amounts of $\mathrm{Nb}$, thus, this material is not expected to be toxic to living cells. However we believe that the influence of niobium ions on the metabolic activity of cells depends on their concentration (availability) in the medium.

Evidences of cell viability also were additionally confirmed by live/dead staining (Figure 4). MG-63 cells grown in the extracts are viable and are homogeneously distributed in the wells while dead cells appear in small quantity, that is, the addition of niobium did not cause a cytotoxic effect on cells.

Table 1. Porosity, compressive strength and relative density $\left(\rho / \rho_{0}\right)$ values for BGNb10 scaffolds.

\begin{tabular}{cccc}
\hline Sample & Porosity (\%) & Compressive strength (MPa) & $\boldsymbol{\rho} / \mathbf{\rho}_{\mathbf{0}}$ \\
\hline BGNb10 & $89.2 \pm 1.4$ & $0.18 \pm 0.03$ & 0.127 \\
\hline
\end{tabular}
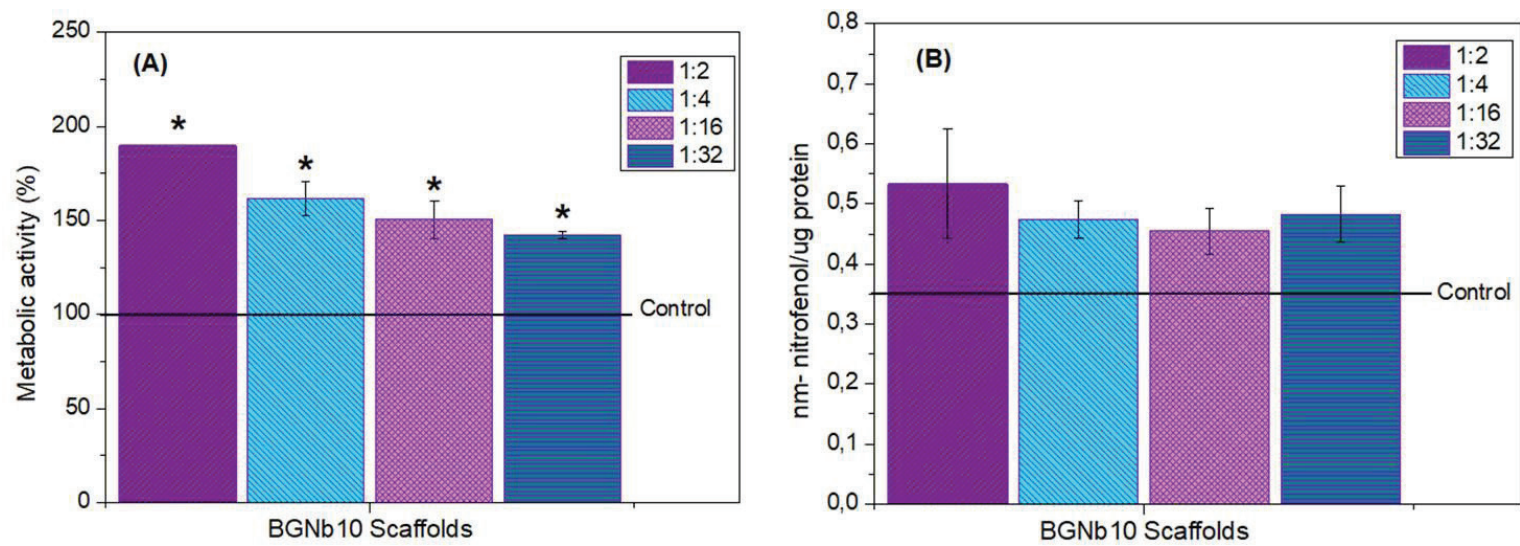

Figure 3. (A) Viability of MG-63 cells after $48 \mathrm{~h}$ in contact with several dilutions of the extracts of BGNb10 scaffolds. Results were expressed as mean \pm standard deviation $(\mathrm{n}=3)$. Statistical analysis was performed using One-way ANOVA followed by post-hoc Tukey HSD multiple comparison test (*p $<0.05)$. (B) ALP activity of MG-63 cells after 6 days of culture with several dilutions of the extracts of BGNb10 scaffolds. 

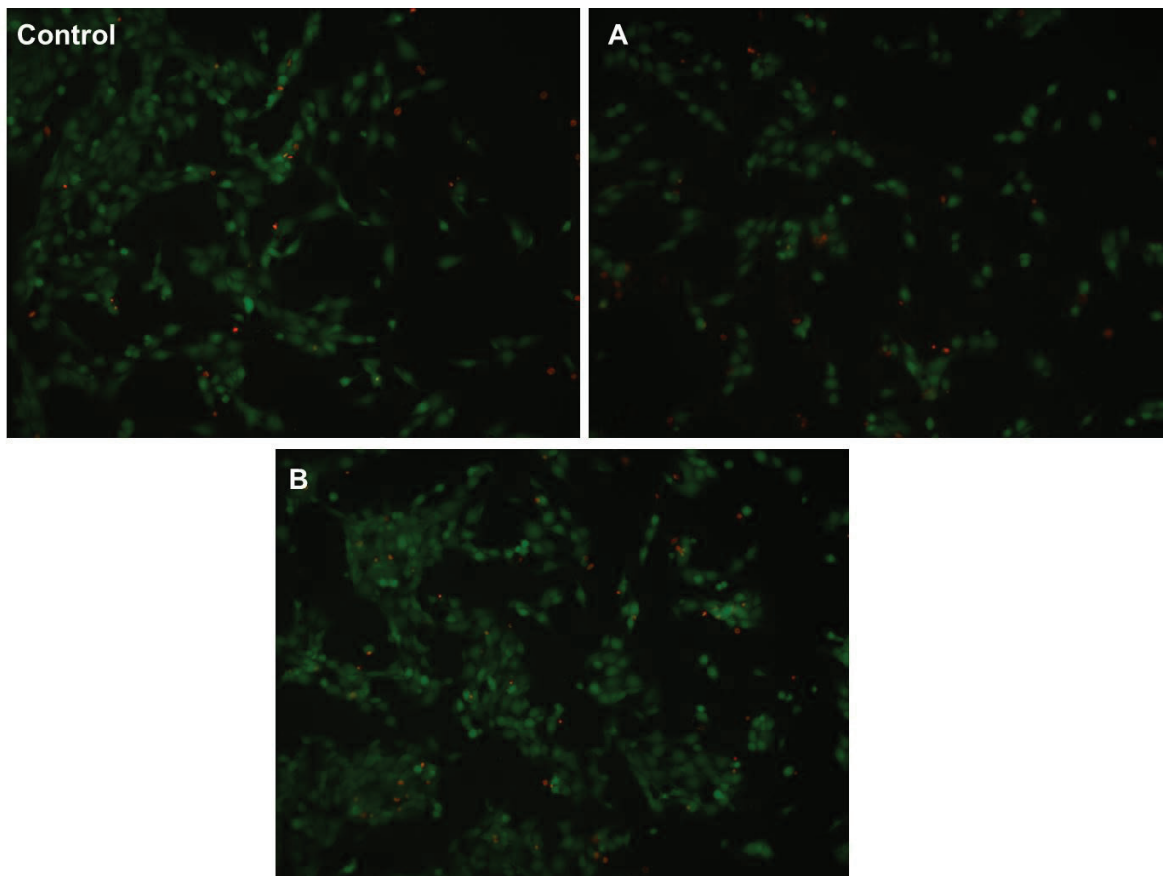

Figure 4. Fluorescence staining of cells cultured on BGNb10 scaffolds: A) 1:2 and B) 1:4 dilution for $24 \mathrm{~h}$.

\section{Conclusions}

BGNb10 scaffolds were successful fabricated by gelcasting method, a simple and cheap method which allowed the obtaining of a $3 \mathrm{D}$ porous structure with interconnected and spherical pores and high porosity $(89 \%)$, similar to the trabecular architecture of spongy bone. The presence of niobium in the glass matrix may have been responsible for stimulation of cell viability and osteogenic parameters. These findings indicate a possible application of the BGNb10 scaffolds for bone tissue engineering.

\section{Acknowledgments}

This work was supported by São Paulo Research Foundation - FAPESP (Grant: 2015-24659-7), National Council for Scientific and Technological Development (Grant: 456461/2014-0) and Erasmus Mundus Program (Be Mundus Project). The authors acknowledge the use of the analytical instrumentation facility at I3S- Instituto de Investigação e Inovação em Saúde (Portugal) and the provision of $\mathrm{Nb}_{2} \mathrm{O}_{5}$ by CBMM - Companhia Brasileira de Metalurgia e Mineração.

\section{References}

1. Siqueira L, Gouveia RF, Grenho L, Monteiro FJ, Fernandes $\mathrm{MH}$, Trichês ES. Highly porous $45 \mathrm{~S} 5$ bioglass-derived glass-ceramic scaffolds by gelcasting of foams. J Mater Sci. 2018;53(15):10718-31.

2. Schuhladen K, Roether JA, Boccaccini AR. Bioactive glasses meet phytotherapeutics: the potential of natural herbal medicines to extend the functionality of bioactive glasses. Biomaterials. 2019;217:119288.

3. Baino F. Bioactive glasses: when glass science and technology meet regenerative medicine. Ceram Int. 2018;44(13):14953-66.
4. Brauer DS. Bioactive glasses: structure and properties. Angew Chem Int Ed. 2015;54(14):4160-81.

5. Salinas AJ, Vallet-Regí M. Glasses in bone regeneration: a multiscale issue. J Non-Cryst Solids. 2016;432:9-14.

6. Marie PJ, Ammann P, Boivin G, Rey C. Mechanisms of action and therapeutic potential of strontium in bone. Calcif Tissue Int. 2001;69(3):121-9.

7. Tanaka T, Kojima I, Ohse T, Ingelfinger JR, Adler S, Fujita $\mathrm{T}$, et al. Cobalt promotes angiogenesis via hypoxia-inducible factor and protects tubulointerstitium in the remnant kidney model. Lab Invest. 2005;85(10):1292-307.

8. Souza LPL, Lopes JH, Ferreira FV, Martin RA, Bertran CA, Camilli JA. Evaluation of effectiveness of 45S5 bioglass doped with niobium for repairing critical-sized bone defect in in vitro and in vivo models. J Biomed Mater Res A. 2020;108(3):446-57.

9. Kushwaha M, Pan X, Holloway JA, Denry IL. Differentiation of human mesenchymal stem cells on niobium-doped fluorapatite glass-ceramics. Dent Mater. 2012;28(3):252-60.

10. Santos FA, Silva AC, Santos C, Simba BG, Bartolomé JF, Duran T, et al. Biocide glass based on $\mathrm{Nb}_{2} \mathrm{O}_{5}-\mathrm{SiO}-\mathrm{CaO}-\mathrm{Na}_{2} \mathrm{O}$ system. Mater Lett. 2016;183:277-80.

11. Souza L, Lopes JH, Encarnação D, Mazali IO, Martin RA, Camilli JA, et al. Comprehensive in vitro and in vivo studies of novel melt-derived $\mathrm{Nb}$-substituted 45S5 bioglass reveal its enhanced bioactive properties for bone healing. Sci Rep. 2018;8(1):12808.

12. Chen QZ, Thompson ID, Boccaccini AR. 45S5 Bioglass ${ }^{\circledR}$ derived glass-ceramic scaffolds for bone tissue engineering. Biomaterials. 2006;27(11):2414-25.

13. Lopes OF, Mendonça VR, Silva FBF, Paris EC, Ribeiro C. Óxidos de nióbio: uma visão sobre a síntese do $\mathrm{Nb}_{2} \mathrm{O}_{5}$ e sua aplicação em fotocatálise heterogênea. Quim Nova. 2015;38(1):106-17.

14. Elsayed H, Romero AR, Molino G, Brovarone CV, Bernardo E. Bioactive glass-ceramic foam scaffolds from 'inorganic gel casting' and sinter-crystallization. Materials. 2018;11(3):349. 
15. Balbinot GS, Collares FM, Visioli F, Soares PBF, Takimi AS, Samuel SMW, et al. Niobium addition to sol-gel derived bioactive glass powders and scaffolds: in vitro characterization and effect on pre-osteoblastic cell behavior. Dent Mater. 2018;34(10):1449-58.

16. Capanema NSV, Mansur AAP, Carvalho SM, Silva ARP, Ciminelli VS, Mansur HS. Niobium-doped hydroxyapatite bioceramics: synthesis, characterization and in vitro cytocompatibility. Materials. 2015;8(7):4191-209.

17. Fernandes MH, Gomes OS. Bone cells dynamics during peri-implantitis: a theoretical analysis. J Oral Maxillofac Res. 2016;7(3):1-19.
18. Hench LL, Splinter RJ, Allen WC, Greenlee TK. Bonding mechanisms at the interface of ceramic prosthetic materials. J Biomed Mater Res. 1971;5(6):117-41.

19. Hench LL, Polak JM, Xynos ID, Buttery LDK. Bioactive materials to control cell cycle. Mater Res Innov. 2000;3(6):313-23.

20. Jones JR. Review of bioactive glass: from Hench to bydrids. Acta Biomater. 2013;9(1):4457-86.

21. Lopes JH, Souza LP, Domingues JA, Ferreira FV, Alencar Hausen $\mathrm{M}$, Camilli JA, et al. In vitro and in vivo osteogenic potential of niobium-doped 45S5 bioactive glass: a comparative study. J Biomed Mater Res B Appl Biomater. 2020;108(4):1372-87. 